\title{
Assessment of Platelet Parameters in Children with Pneumonia
}

\section{Pnömonili Çocuklarda Trombosit Parametrelerinin Değerlendirilmesi}

\author{
Musa Şahin', Nilgün Selçuk Duru², Murat Elevli², Mahmut Civilibal ${ }^{3}$ \\ ${ }^{1}$ Clinic of Pediatric Health and Diseases, Kiziltepe State Hospital, Mardin, Turkey \\ ${ }^{2}$ Clinic of Pediatric Health and Diseases, Health Sciences University, Haseki Training and Research Hospital, Istanbul, Turkey \\ ${ }^{3}$ Clinic of Pediatric Health and Diseases, Memorial Hospital, Istanbul, Turkey
}

\begin{abstract}
Objective: The aim of this study is to compare the platelet count, mean platelet volume (MPV), platelet distribution width (PDW) and plateletcrits (PCT) of patients with pneumonia with those of healthy controls, and to investigate the correlation of the disease with other laboratory parameters.

Material and Methods: One hundred and ninety child patients with pneumonia and 71 healthy children were included in the study and their platelet parameters were compared, with correlations examined between the clinical and laboratory parameters of patients with pneumonia and platelet parameters. The data analysis was carried out using the SPSS for Windows version 15.0 program

Results: No significant difference was observed between the groups in terms of age or gender, while the leucocyte, platelet count and PCT of the patients with pneumonia was statistically significantly higher in the patient group than in the control group $(p<0.05)$. The MPV and PDW values of the patients with pneumonia were statistically significantly lower than those of the control group $(p<0.05)$. In the pneumonia and control groups, MPV was found to be significantly positively correlated with age and hemoglobin, but had a significant negative correlation with platelet count (pneumonia group $p=0.046, p=0.008, p<0.001$; control group $p=0.002, p=0.019, p=0.003$, respectively). In the pneumonia group, PDW was found to have a significant positive correlation with leucocyte and hemoglobin, and a significant negative correlation with platelet $(p=0.006, p=0.018 p<0.001$, respectively). On the other hand, PCT was identified to have a statistically significant positive correlation only with platelet $(p<0.001)$. The patients were divided into two groups based on hospitalization duration. No significant difference was observed in the platelets parameters of the two groups.
\end{abstract}

Özet

Giriş: Çalışmamızda pnömoni tanısı ile izlenen hastaların trombosit, ortalama trombosit hacmi (MPV), trombosit dağılım aralığı (PDW), plateletkrit (PCT) değerlerinin sağlıklı kontrol grubuyla karşılaştırılması ve ayrıca yatış sürelerine ve komplikasyon gelişmesine göre farklılık gösterip göstermediğinin belirlenmesi amaçlandı.

Gereç ve Yöntemler: Çalışmaya 190 pnömoni hastası ile 71 sağlıklı çocuk alındı. Gruplar trombosit parametreleri yönünden karşılaştırıldı. Pnömonili olguların klinik ve laboratuvar bulguları ile trombosit parametreleri arasındaki ilişki incelendi. Verilerin analizi SPSS for Windows 15.0 programında yapıldı.

Bulgular: Gruplar arasında yaş ve cinsiyet açısından anlamlı farklılık yoktu. Hasta grupta lökosit, trombosit sayısı ve PCT ortalaması kontrol grubuna göre istatistiksel olarak anlamlı yüksek bulunurken $(p<0.05)$ $M P V$ ve PDW ortalaması anlamlı olarak düşüktü $(p<0.05)$. MPV hasta ve kontrol grubunda yaş ve hemoglobin ile pozitif yönde trombosit sayısı ile negatif yönde (hasta grubunda $p=0.046, p=0.008 p<0.001$; kontrol grubunda $p=0.002, p=0.019, p=0.003$, sırası ile) istatistiksel olarak anlamlı ilişkiliydi. PDW hastalarda lökosit ve hemoglobin ile pozitif yönde trombosit ile negatif yönde $(p=0.006 p=0.018 p<0.001$ sırası ile) istatistiksel olarak anlamlı olarak ilişkiliydi. PCT trombosit ile çok iyi derecede pozitif yönde $(p<0.001)$ istatistiksel olarak anlamlı ilişkili bulundu. Olgular hastanede yatış sürelerine göre 14 gün ve altı ve 14 gün üstü yatanlar olarak iki gruba ayrıldı. Gruplar arasında trombosit parametreleri açısından anlamlı farklılık gözlenmedi.

Sonuç: Çalışmamızda trombosit parametreleri; pnömonili hastalarda sağlam çocuklardan anlamlı farklılıklar gösterdi. Pnömonili çocukların İstanbul-Türkiye

E-mail: nilgunduru@yahoo.com OCopyright 2017 by Pediatric
Infectious Diseases Society -Available online at www.cocukenfeksiyon.org OTelif Hakkı 2017 Çocuk Enfeksiyon Hastalıkları Derneği -Makale metnine www.cocukenfeksiyon.org web sayfasından ulaşılabilir 
Conclusion: Significant differences were identified between the patients with pneumonia and the healthy controls in terms of platelet parameters. Further studies are required to confirm whether platelet volume parameters are decisive laboratory parameters for the follow-up of pneumonia.

Keywords: Pneumonia, platelet count, mean platelet volume, platelet distribution width, plateletcrit, children

\section{Introduction}

Pneumonia is the inflammation of lung tissue in the alveoli and interstitium due to infectious and non-infectious factors, and is one of the primary causes of child mortality in developing countries, resulting each year in death of 1.1-1.4 million children worldwide (1).

In many pediatric patients, the diagnosis of pneumonia is based on clinical symptoms and findings, and in addition to clinical and radiological findings, certain non-specific laboratory parameters are used in the follow-up period of patients with pneumonia. Platelets have long been known to act as acute phase reactants in inflammatory diseases, yet mean platelet volume (MPV) and platelet distribution width (PDW), as significant indicators of platelet activation and function, are often disregarded. In recent years, studies of infectious and systemic diseases have revealed significant findings related to not only platelet numbers, but also MPV and PDW $(2,3)$.

In this study, we compare the platelet count, and plateletcrit (PCT), MPV and PDW levels of patients with pneumonia at the time of diagnosis with those of healthy children. By comparing the groups in terms of duration of hospital stay and rate of complications, we aim to identify whether or not these parameters can be predictive for the follow-up of pneumonia.

\section{Materials and Methods}

The medical records of 190 patients, of which 79 (41.6\%) were female and 111 (58.4\%) were male, and who were admitted to hospital with a diagnosis of community-acquired pneumonia (CAP) between January 2008 and June 2013, were examined retrospectively. The control group consisted of 71 healthy children, including 36 female (50.7\%) and 35 male (49.3\%) with the same age range. An application was made for ethics committee approval for the study, however, it was determined that no ethics committee approval was required due to the retrospective nature of the study (Decision no: 3108/07/2013). Inclusion criteria were: aged 2-18 years, and with clinical and radiological findings consistent with a diagnosis of pneumonia. For all patients, the diagnosis of pneumonia was made according to the current guidelines, including: coughing, wheezing, fever, cyanosis and difficulty in breath- izleminde trombosit parametrelerinin belirleyici olup olmayacağını saptamak için konu ile ilgili daha kapsamlı çalışmalar gereklidir.

Anahtar Kelimeler: Pnömoni, trombosit, ortalama trombosit hacmi, trombosit dağılım aralığı, plateletkrit, çocuklar

ing; and the detection of tachypnea, apnea, cyanosis, sighing respiration, detection of rale and rhoncus with auscultation during physical examination; anterior and posterior chest $X$-Rays; and laboratory findings (4). A radiological examination was performed to make a differentiation between lobar pneumonia and bronchopneumonia. Patients with tuberculosis, acute bronchiolitis, asthma, hematologic diseases, immunosupression or comorbid diseases were excluded from the study. In addition, patients who were admitted to the hospital for other reasons and were believed to have pneumonia as a hospital-acquired infection at least 48 hours after admission were also excluded from the study. The control group comprised healthy children who were admitted to the hospital for other reasons (preparation for surgery, growth control, etc.) who had no acute and/or chronic disease, had no complaints of coughing, wheezing, fever, etc. consistent with pneumonia, and had no rale or rhoncus in lung auscultation. The patient group was referred to as Group I, and control group was referred to as Group II in the study.

The medical records of patients were examined, and gender, date of birth, age (years), duration of hospital stay (day), development of complications, serum creatinine, glucose, urea, hemoglobin, leukocyte count, erythrocyte sedimentation rate (ESR), CRP, MPV, PDW, PCT, and platelet counts were all recorded. The demographic features and hemogram values of the healthy controls in Group II were also recorded, and Group I and Group II were compared with respect to age, gender and platelet parameters. The patients were divided into two groups with respect to duration of hospital stay, as $\leq 14$ and $14>$ days. The groups were evaluated in terms of platelet parameters, biochemical examinations, acute phase reactants and radiological findings, and development of pleurisy, empyema, and atelectasis was recorded as complications.

Blood samples were collected from Group I during hospitalization and from Group II at the time of admission, and the samples were analyzed on an ABX Pentra DX 120 hemogram device (Horiba, Japan). A normal platelet count was accepted as 15.0000-450.000/uL in children and 6.5-12.0 fL for MPV, 0.10-0.28\% for PCV and 15.0-17.0 10 GSD for PDW were accepted as normal according to the hospital laboratory data. 


\section{Statistical Analysis}

The SPSS Statistics for Windows version 15.0 program (SPSS Inc., Chicago, IL, USA) was used for the statistical analysis. Descriptive statistics were presented as numbers and percentages for categorical variables, while numeric variables were expressed as mean, standard deviation and median. For variables that followed a normal distribution, a Student's T-test was used to compare the differences between two groups, while variables with an abnormal distribution were subjected to a Mann-Whitney U-test to compare the differences between the two groups. For multiple group comparisons, a Kruskal-Wallis test was used, as none of the variables followed a normal distribution. A Mann-Whitney U-test with a Bonferroni correction was used for subgroup analyses. A Spearman correlation analysis was used for numerical variables with an abnormal distribution, and a Chi-square test was used to compare categorical variables among the independent groups. A $p$ value of $<0.05$ was considered statistically significant.

\section{Results}

Group I comprised 190 patients with pneumonia, of which 79 (41.6\%) were female and 111 (58.4\%) were male. The mean age of the patients was $8.82 \pm 4.61$ years. Group II comprised 71 control patients, of which 36 (50.7\%) were female and 35 (49.3\%) were male. The mean age of the control group was $9.39 \pm 4.60$ years. Groups I and II were similar in terms of age $(\mathrm{p}=0.324)$ and male-to-female ratio $(\mathrm{p}=0.186)$ (Table 1$)$.

MPV $(p<0.001)$ and PDW $(p=0.034)$ levels were found to be significantly lower in Group I than in Group II, however PCT was significantly higher in Group I than in Group II $(p=0.008)$ (Table 1). A comparison of the other laboratory parameters of Groups I and II revealed that the leukocyte count $(p<0.001)$ and platelet count $(p<0.001)$ were significantly higher in Group I, and that hemoglobin levels were significantly lower in Group I ( $p<0.001$ ) (Table 1).

In Group I, PDW showed a positive correlation with age and hemoglobin level ( $p=0.046, p=0.008$, respectively), but a negative significant correlation with platelet count $(p<0.001)$. Similarly, in Group II, a positive relationship was observed between PDW and age $(p=0.002)$ and hemoglobin level $(p=0.019)$, while PDW had a negative statistically significant relationship with platelet count $(p=0.003)$ (Table 2$)$.

In Group I, PCT showed a positive correlation with platelet count $(p<0.001)$ and ESR $(p=0.007)$, sodium levels $(p=0.013)$, and a negative correlation with neutrophil count $(p=0.013)$. In Group II, PCT showed a positive correlation with leukocyte count $(p=0.021)$ and platelet count $(p<0.001)$ that was statistically significant (Table 2 ).

In Group 1, 153 patients (85.5\%) had a duration of hospital stay of $\leq 14$ days, while 37 patients $(15.5 \%)$ had hospital stays of $>14$ days. After dividing the patient group into two subgroups based on duration of hospital stay, and comparing these subgroups independently with the control group in terms of age, gender, hematologic parameters, radiologic findings and development of complications, no significant difference was observed between either patient group and the control group with respect to age $(p=0.366)$. The male-to-female ratio was similar between the patients with hospital stays of $\leq 14$ days and the control subjects, while the male-to-female ratio of the patients with hospital stays of $>14$ days were significantly lower than in the control group $(p=0.026)$. Patients with hospital stays of $>14$ days had the highest male ratio $(75.68 \%)$ when compared to patients with a length of stay of $\leq 14$ days (54.25\%) and the controls (46\%). The leukocyte count was significantly lower in Group II than in the relevant subgroups of

Table 1. Comparison of the demographic characteristics and laboratory test results of the patient and control groups

\begin{tabular}{|c|c|c|c|}
\hline & Patients $(n=190)$ & Controls $(n=71)$ & $\mathbf{p}$ \\
\hline Parameter (Mean \pm SD) & $8.82 \pm 4.61(8)$ & $9.39 \pm 4.60(10)$ & NS \\
\hline \multicolumn{4}{|l|}{ Age (years) (median) } \\
\hline Female & $79(41.58)$ & $36(50.70)$ & NS \\
\hline Male & $111(58.42)$ & $35(49.30)$ & \\
\hline Hemoglobin, g/dL & $11.64 \pm 1.58(11.60)$ & $12.47 \pm 1.52(12.50)$ & $<0.001$ \\
\hline $\mathrm{MPV}, \mathrm{fL}$ & $7.78 \pm 0.89(7.80)$ & $8.38 \pm 0.93(8.30)$ & $<0.001$ \\
\hline PDW, 10GSD & $13.90 \pm 2.33(14.00)$ & $14.74 \pm 2.11(14.50)$ & 0.034 \\
\hline PCT, \% & $0.29 \pm 0.11(0.26)$ & $0.24 \pm 0.06(0.24)$ & 0.008 \\
\hline
\end{tabular}


Table 2. Correlations between MPV, PDW and PCT with other laboratory parameters

\begin{tabular}{|c|c|c|c|c|c|c|c|}
\hline & & \multicolumn{2}{|c|}{ MPV } & \multicolumn{2}{|c|}{ PDW } & \multicolumn{2}{|c|}{ PCT } \\
\hline & & rho & $\mathbf{p}$ & rho & $\mathbf{p}$ & rho & $\mathbf{p}$ \\
\hline \multirow[t]{12}{*}{ Group I } & Age, years & 0.146 & 0.046 & 0.029 & NS & 0.137 & NS \\
\hline & Leukocyte, $10^{3} / \mathrm{mm}^{3}$ & 0.050 & NS & 0.200 & 0.017 & 0.114 & NS \\
\hline & Platelet, $10^{3} / \mathrm{mm}^{3}$ & -0.391 & $<0.001$ & -0.346 & $<0.001$ & 0.891 & $<0.001$ \\
\hline & Hemoglobin, g/L & 0.194 & 0.008 & 0.176 & 0.036 & -0.062 & NS \\
\hline & $\mathrm{Na}, \mathrm{mEq} / \mathrm{L}$ & 0.041 & NS & -0.018 & NS & 0.178 & 0.041 \\
\hline & Urea, mg/dL & -0.018 & NS & 0.028 & NS & 0.122 & NS \\
\hline & Glucose mg/dL & 0.060 & NS & 0.141 & NS & -0.122 & NS \\
\hline & Creatinine, mg/dL & 0.123 & NS & 0.121 & NS & 0.015 & NS \\
\hline & CRP, mg/dL & 0.027 & NS & 0.016 & NS & -0.129 & NS \\
\hline & ESR, mm/hour & -0.122 & NS & -0.032 & NS & 0.242 & 0.007 \\
\hline & Neutrophil, $10^{3} / \mathrm{mm}^{3}$ & 0.036 & NS & 0.187 & 0.024 & -0.210 & 0.013 \\
\hline & Length of stay & -0.041 & NS & -0.089 & NS & 0.098 & NS \\
\hline \multirow[t]{4}{*}{ Group II } & Age, years & 0.362 & 0.002 & 0.370 & 0.002 & -0.199 & NS \\
\hline & Leukocyte, $10^{3} / \mathrm{mm}^{3}$ & -0.033 & NS & 0.102 & NS & 0.283 & 0.021 \\
\hline & Platelet, $10^{3} / \mathrm{mm}^{3}$ & -0.351 & 0.003 & -0.363 & 0.003 & 0.813 & $<0.001$ \\
\hline & Hemoglobin, g/L & 0.278 & 0.019 & 0.258 & 0.037 & -0.025 & $A D$ \\
\hline
\end{tabular}

Table 3. Comparison of clinical parameters with respect to length of stay

\begin{tabular}{|c|c|c|c|c|}
\hline $\begin{array}{l}\text { Parameter } \\
(\text { Mean } \pm \text { SD) }\end{array}$ & $\begin{array}{c}\leq 14 \text { days } \\
n=153\end{array}$ & $\begin{array}{c}>14 \text { days } \\
n=37\end{array}$ & $\begin{array}{c}\text { Control subjects } \\
n=71\end{array}$ & $\mathbf{P}$ \\
\hline Age (years) & $8.67 \pm 4.62(8)$ & $9.43 \pm 4.57(10)$ & $9.39 \pm 4.60(10)$ & 0.366 \\
\hline \multicolumn{5}{|l|}{ Gender n (\%) } \\
\hline Female & $70(45.75)$ & $9(24.32)$ & $36(50.70)$ & 0.026 \\
\hline Male & $83(54.25)$ & $28(75.68)$ & $35(49.30)$ & \\
\hline Leukocyte count & $15.52 \pm 8.61(13.3)^{*}$ & $15.01 \pm 8.53(13.6)^{*}$ & $8.46 \pm 3.53(7.60)^{* \#}$ & $<0.001$ \\
\hline Platelet count & $377.23 \pm 151.50(341)^{*}$ & $388.00 \pm 164.31(329)$ & $293.85 \pm 70.16(286.00)^{*}$ & $<0.001$ \\
\hline Hemoglobin & $11.70 \pm 1.60(11.7)^{*}$ & $11.39 \pm 1.48(11.5)^{¥}$ & $12.47 \pm 1.52(12.50)^{* \#}$ & $<0.001$ \\
\hline MPV & $7.74 \pm 0.86(7.8)^{¥}$ & $7.93 \pm 0.99(7.7)^{¥}$ & $8.38 \pm 0.93(8.30)^{* \#}$ & $<0.001$ \\
\hline PDW & $13.88 \pm 2.30(14)$ & $14.00 \pm 2.49(15.4)$ & $14.74 \pm 2.11(14.50)$ & 0.103 \\
\hline PCT & $0.28 \pm 0.11(0.26)$ & $0.31 \pm 0.11(0.31)^{*}$ & $0.24 \pm 0.06(0.24)^{\#}$ & 0.010 \\
\hline $\mathrm{Na}$ & $135.59 \pm 3.60(136)$ & $135.21 \pm 2.82(135)$ & & 0.437 \\
\hline Urea & $23.56 \pm 7.86(23)$ & $26.03 \pm 8.65(25)$ & & 0.117 \\
\hline Glucose & $107.83 \pm 48.19(98)$ & $97.90 \pm 27.13(97)$ & & 0.786 \\
\hline Creatinine & $0.61 \pm 1.76(0.47)$ & $0.49 \pm 0.18(0.48)$ & & 0.733 \\
\hline CRP & $31.28 \pm 61.76(7.58)$ & $27.15 \pm 50.01(15)$ & & 0.060 \\
\hline Sedimentation & $55.71 \pm 31.19(57)$ & $59.89 \pm 31.11(62)$ & & 0.484 \\
\hline Neutrophil ratio & $67.59 \pm 18.32(70)$ & $69.72 \pm 16.29(65.5)$ & & 0.529 \\
\hline Length of stay & $8.35 \pm 3.25(8)$ & $19.27 \pm 7.42(15)$ & & $<0.001$ \\
\hline $\begin{array}{l}\text { Radiology n (\%) } \\
\text { Bronchopneumonia }\end{array}$ & $79(51.63)$ & $12(32.43)$ & & 0.036 \\
\hline Lobar pneumonia & $74(48.37)$ & $25(67.57)$ & & \\
\hline Complications n (\%) & $11(7.19)$ & $13(35.14)$ & & $<0.001$ \\
\hline
\end{tabular}


Şahin et al.

Table 4. Comparison of mean MPV, PDW and PCT values between bronchopneumonia and lobar pneumonia

\begin{tabular}{|l|c|c|c|}
\hline & MPV & PDW & PCT \\
\hline Bronchopneumonia & $7.71 \pm 0.86(7.7)$ & $13.62 \pm 3.35(14.05)$ & Mean \pm SD (median) \\
\hline Lobar pneumonia & $7.83 \pm 0.91(7.8)$ & $13.62 \pm 2.72(13.9)$ & $0.28 \pm 0.11(0.255)$ \\
\hline P & NS & NS & $0.29 \pm 0.11(0.27)$ \\
\hline MPV: Mean platelet volume, PDW: Platelet distribution width, PCT: Plateletcrit, NS: Not significant. & NS \\
\hline
\end{tabular}

Table 5. Comparison of MPV, PDW and PCT between patients with complications and patients without complications

\begin{tabular}{|l|c|c|c|}
\hline & $\begin{array}{c}\text { MPV } \\
\text { Mean } \pm \text { SD (median) }\end{array}$ & $\begin{array}{c}\text { PDW } \\
\text { Mean } \pm \text { SD (median) }\end{array}$ & $\begin{array}{c}\text { PCT } \\
\text { Mean } \pm \text { SD (median) }\end{array}$ \\
\hline Without complications & $7.76 \pm 0.87(7.8)$ & $13.80 \pm 2.84(14)$ & $0.28 \pm 0.11(0.26)$ \\
\hline With complications & $7.87 \pm 0.99(7.7)$ & $12.32 \pm 3.99(12.7)$ & $0.34 \pm 0.15(0.29)$ \\
\hline P & NS & NS & NS \\
\hline MPV: Mean platelet volume, PDW: Platelet distribution width, PCT: Plateletcrit, NS: Not significant. \\
\hline
\end{tabular}

Group I ( $p<0.001)$, and both Hg and MPV levels were significantly higher in the control group $(p<0.001, p<0.001)$. Platelet counts were found to be statistically significantly higher in the patient group with a length of hospital stay of $\leq 14$ days $(p<0.001)$, whereas PCT was statistically significantly higher in the patient group with a length of hospital stay $>14$ days $(p=0.010)$. No significant differences were identified in the remaining hematologic parameters between the groups. Radiological evaluations showed that the frequency of lobar pneumonia was significantly higher in patients hospital stays of $>14$ days (67.57\%) compared to patients with a length of stay of $\leq 14$ (48.37\%). However, the frequency of bronchopneumonia was significantly lower in patients with a length of hospital stay of $>14$ days (32.43\%) when compared to patients with a length of stay of $\leq 14$ days $(51.63 \%)(p=0.036)$. In addition, the rate of complications was higher in patients with a length of stay $>14$ days than in other patient group $(35.14 \%$ vs. $7.19 \%$; $\mathrm{p}<0.001$ ) (Table 3).

After dividing the patient groups into subgroups based on the pneumonia type, as identified from a chest X-Ray (bronchopneumonia or lober pneumonia), the mean MPV, PDW, and PCT values showed no statistically significant differences (Table 4). Similarly, no significant relationship was observed in terms of mean MPV, PDW and PCT values in the patient groups with complications (atelectasis, empyema, pleurisy) and those without complications (Table 5).

\section{Discussion}

Leukocyte count, ESR, CRP and procalcitonin are the most commonly used acute phase reactants in clinical practice, although platelet parameters, including platelet count, MPV and PDW, can also act as acute phase reactants in inflammatory diseases (3).

Secondary thrombocytosis is a common finding in pediatric patients with infections (5-7). Platelets and leukocytes are activated in response to microbial infections, and the response of platelets shows similarities to the response mediated by leukocytes. Leukocytes ingest bacteria, while platelets encapsulate microorganisms in phagosome-like vacuoles, which allows the rapid clearance of pathogens (8). Thrombocytosis is more common in bone, joint and pleural cavity infections, and although it is known to occur more often in bacterial infections with a more severe clinical progression, elevated platelet counts are also reported in bronchiolitis with viral etiology, as well as pneumonia (9-11). In this study, patients with pneumonia had significantly higher platelet counts than the control subjects $(p<0.001)$. While our results are consistent with literature, we were unable to determine the cause of infections, and so were unable to explore any correlations between platelet count and the causative agent of the infection.

An elevated or suppressed platelet count in patients with CAP is associated with higher mortality and complication rates. Prina et al. carried out a study of 2.423 patients with CAP, and reported that 2 percent had thrombocytopenia, 8 percent had thrombocytosis and 90 percent had normal platelet counts (12). The same study revealed also that complicated pleural effusion and empyema were more common in patients with thrombocytosis, while severe sepsis, septic shock and intensive care unit hospitalization were seen more in patients with thrombocytopenia, to a significant degree. Patients with abnormal platelet counts had longer hospital stays and higher mortality and rehospitalization rates. Taken together, 
the authors concluded that thrombocytosis could be used to evaluate disease severity (12). In another study, Mirsaeidi et al. reported a significant correlation between thrombocytopenia and thrombocytosis and mortality, and thrombocytosis was shown to be independently correlated with the length of hospital stay in patients with CAP (8). The authors also suggested that platelet count anomalies were more useful than leukocyte count anomalies in determining the prognosis of patients with pneumonia. Other studies including pediatric patients have reported similar correlations between thrombocytosis and a poor clinical outcome in patients with pneumonia $(9,13)$.

As none of our patients died, we were unable to assess the correlation between mortality rate and prognosis. Patients with a length of stay of $>14$ days had significantly higher platelet counts than those with a length of stay of $\leq 14$ days and the control subjects, although the mean platelet counts of all three groups were within the normal range. Mild thrombocytopenia was observed in only two patients at a range of 150.000-100.000). Prina et al. reported that the majority of patients with thrombocytopenia also had chronic heart and lung disease, whereas patients with chronic diseases were excluded from the present study (12).

Both platelet count and size can change in relation to its function. An increase in MPV occurs in response to thrombopoietic stress, together with increased megakaryocte expansion. An evaluation of MPV and PDW together ensures a more accurate definition of platelet volume distribution, and is a measure of differences in platelet volumes. PCT, on the other hand, indicates the percentage of platelets in a given blood count (14-16).

Platelet volume shows variations under different clinical conditions. There have been many studies exploring the relationship between MPV and various inflammatory diseases, including cystic fibrosis, ulcerative colitis, rheumatoid arthritis, FMF, neonatal RDS, upper urinary system infections and sepsis, while studies on the clinical utility of PDW and PCT are limited in number (17-23).

In the current study, we determined that patients with pneumonia had significantly higher leukocyte counts and PCT than the controls, although the mean hemoglobin, MPV and PDW levels were lower in patients with pneumonia. No correlation was identified between platelet parameters and duration of hospital stay, although PCT was found to be significantly higher in patients with a length of stay $>14$ days, and the rate of complications was also higher for this group.

Previous studies have suggested two mechanisms for explaining the role of platelets in pneumonia. The first involves the activation of systemic inflammation. Platelets stimulate chemotaxis, which results in the secretion of various proin- flammatory cytokines (2). IL-6, a cytokine with a central role in inflammation in CAP, is believed to affect MPV, and cytokines such as IL-3 and IL-6 trigger megakaryocytes, and induce the production of larger and more reactive platelets (24). IL-6 levels are correlated with disease severity in children with CAP $(25,26)$.

The second mechanism holds platelet-induced thrombus formation responsible, and the correlation between pneumonia and myocardium infarction in adults further supports this hypothesis (27).

Karadag-Oncel et al. reported lower MPV values in patients with pneumonia than in their control group (3). Patients with more severe disease (requiring hospitalization) had significantly higher MPV values than the patients followed up as outpatients. One interpretation of these findings is that MPV values increase in cases of severe pneumonia and decrease in milder cases. Alternatively, given that patients who require hospitalization are usually admitted to the hospital at a later stage of the disease, it is possible that MPV decreases during the earlier stages of CAP, and this is followed by a significant increase in response to bone marrow activation (3). Robbins et al. reported that changes in platelet size follow at least two distinct patterns: an early increase in MPV in severe infections (such as septicemia), and a late decrease in chronic bacterial infections, which may explain why patients with pneumonia have lower MPV levels than controls (28). In addition, the present study is based on examinations made at the time of hospitalization, which may also have an effect the observations, as we were unable to measure and compare the changes in platelet parameters at different times during disease progression, which is the main limitation of our retrospective study.

\section{Conclusion}

This study has identified significant differences in the platelet parameters of patients with pneumonia and the controls, although the durations of hospital stay and complication rates were not correlated with these parameters. Taken together, while platelet parameters currently lack the power to indicate disease severity, we believe that their clinical use will increase as the relationship between platelets and infectious diseases is revealed through future studies.

Ethics Committe Approval: The study was retrospective. The ethics committee of the University Health Sciences Haseki Training and Research Hospital decided that the approval of the ethics committee was not necessary with the decision no. 31 and date of 08/07/2013.

Informed Consent: Patient consent was not received since this required archival studies.

Peer-review: Externally peer-reviewed. 
Author Contributions: Concept - NSD; Design - NSD; Supervision - ME, MC; Data Collection and/or Processing - MS; Analysis and/or Interpretation - NSD; Literature Review - MS; Writing - NSD; Critical Review - All of authors.

Conflict of Interest: The authors have not reported a conflict of interest.

Financial Disclosure: There is no financial support in this study.

\section{References}

1. He C, Kang L, Miao L, et al. Pneumonia Mortality among Children under 5 in China from 1996 to 2013: An Analysis from National Surveillance System. PLoS One 2015;10:e0133620.

2. Elzey $B D$, Sprague $D L$, Ratliff $T L$. The emerging role of platelets in adaptive immunity. Cell Immunol 2005;238:1-9.

3. Karadag-Oncelt, Ozsurekci Y, Kara A, Karahan S, Cengiz AB, Ceyhan M. The value of mean platelet volume in the determination of community acquired pneumonia in children. Ital J Pediatr 2013;39:16.

4. Türk Toraks Derneği Çocuklarda Toplumda Gelişen Pnömoni Tanı ve Tedavi Uzlası Raporu 2009. Toraks Dergisi 2009;10(Ek-3)

5. Chen HL, Chiou SS, Sheen JM, Jang RC, Lu CC, Chang TT. Thrombocytosis in children at one medical center of southern Taiwan. Acta Paediatr Taiwan 1999;40:309e13.

6. Indolf G, Catania P, Bartolini $E$, et al. Incidence and clinical significance of reactive thrombocytosis in children aged 1 to 24 months, hospitalized for community-acquired infections. Platelets 2008;19:409-14.

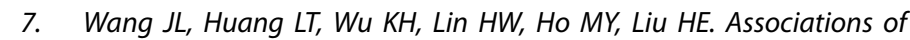
reactive thrombocytosis with clinical characteristics in pediatric diseases. Pediatr Neonatol 2011;52:261-6.

8. Mirsaeidi M, Peyrani P, Aliberti $S$, et al. Thrombocytopenia and thrombocytosis at time of hospitalization predict mortality in patients with community-acquired pneumonia. Chest 2010;137:416-20.

9. Wolach B, Morag H, Drucker M, Sadan N. Thrombocytosis after pneumonia with empyema and other bacterial infections in children. Pediatr Infect Dis J 1990;9:718-21.

10. Zheng SY, XIaO QY, Xie Xh, et al. Association between secondary thrombocytosis and viral respiratory tract infections in children. Sci Rep 2016:6:22964.

11. Kim JK, Jeon JS, Kim JW, Kim GY.Correlation between abnormal platelet count and respiratory viral infection in patients from Cheonan, Korea. $J$ Clin Lab Anal 2016;30:185-9.

12. Prina E, Ferrer M, Ranzaniot, et al. Thrombocytosis is a marker of poor outcome in community-acquired pneumonia. Chest 2013;143:767-75.
13. Dodig S, Raos M, Kovac K, et al. Thrombopoietin and interleukin-6 in children with pneumonia-associated thrombocytosis. Arch Med Res 2005;362:124-8.

14. Dow RB. The clinical and laboratory utility of platelet volume parameters. Aust J Med Sci 1994;15:12-5.

15. Rowan RM. Platelet size distribution analysis: principles techniques and potential clinical utility. Hematol Rev 1986;1:109-44.

16. Kim KY, Kim KE, Kim KH. Mean platelet volume in the normal state and in various clinical disorders. Yonsei Med J 1986;27:219-26.

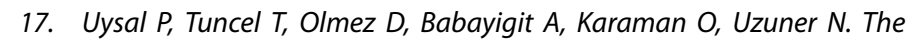
role of mean platelet volume predicting acute exacerbations of cystic fibrosis in children. Ann Thorac Med 2011;6: 227-30.

18. Yüksel 0 , Helvacl K, Başar $O$, et al. An overtooked Indicator of disease activity in ulcerative colitis: mean platelet volume. Platelets 2009;20:277-81.

9. Yazicis, Yazici M, ErerB, Calik Y, Ozhan H, Ataoglus. The plateletindices in patients with rheumatoid arthritis: mean platelet volume reflects disease activity. Platelets 2010;21:122-5.

20. Makay $B$, Türkyilmaz Z, UnsalE. Mean platelet volume in children with familial Mediterranean fever. Clin Rheumatol 2009;28:975-8.

21. Canpolat FE, YuraakoK $\mathrm{VI}$, ArmangIIV, YIgIt S. MVean platelet volume in neonatal respiratory distress syndrome. Pediatr Int 2009;51:314-6.

22. CatalF, Bavbek N, Bayrak U, et al. Platelet parameters In chidaren with upper urinary tract infection: is there a specific response? Ren Fail 2008;30:377-81.

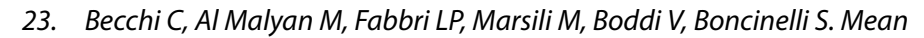
platelet volume trend in sepsis: is it a useful parameter? Minerva Anestesiol 2006;72:749-56.

24. Debili N, Massé JM, Katz A, Guichard J, Breton-Gorius J, Vainchenker W. Effect of the recombinant hematopoetic growth factors interleukin-3, interleukin-6, stem cell factor and leukemia inhibitory factor on the megacaryocytic differantiation of CD34+ cells. Blood 1993;82:84-95.

25. Antumes G, Evarns SA, Lordan Jt, Frew AJ. Systemric cytokine tevels int community-acquired pneumonia and their associa-tion with disease severity. Eur Respir J 2002;20:990-5.

26. Michelow IC, Katz K, McCracken GH, Hardy RD. Systemic cytokine profile in children with community-acquired pneumonia. Pediatr Pulmonol 2007:42:640-5.

27. Ramirez JA, Alibertis, Mirsaeidi M, et al. Acute myocardial infarction in hospitalized patients with community-acquired pneumonia. Clin Infect Dis 2008;47:182-7.

28. Robbins G, Barnard DL. Mean platelet volume changes in Infection.J Clin Pathol 1983;36:1320. 